\title{
Assessment of coronary endothelial function using blood oxygenation level dependant cardiovascular magnetic resonance imaging (BOLD-CMR) in a canine model
}

\author{
Flewitt A Jacqueline ${ }^{1 *}$, Matthias Vöhringer ${ }^{2}$, Jordin D Green ${ }^{3}$, Todd Anderson ${ }^{4}$, John V Tyberg ${ }^{4}$, \\ Matthias G Friedrich'
}

From 2011 SCMR/Euro CMR Joint Scientific Sessions

Nice, France. 3-6 February 2011

\section{Objective}

To test whether BOLD-CMR can detect endotheliumdependent coronary vasodilatation.

\section{Background}

Endothelial function is important in the pathogenesis of atherosclerosis. Whereas endothelial function of peripheral circulation can be assessed non-invasively with Flow-Mediated Dilatation, no method exists for coronary circulation. BOLD-CMR utilizes inherent contrast, where the signal intensity (SI) is linearly correlated with the regional tissue level of deoxygenated hemoglobin. This technique may have potential to assess coronary endothelial function non-invasively.

\section{Methods}

In 6 anesthetized dogs, after instrumentation of the left circumflex coronary (LCx) artery with a coronary infusion catheter and an extravascular flow probe, the coronary endothelium was activated with acetylcholine (ACh). Using a clinical 1.5-T MRI (MAGNETOM Avanto, Siemens Healthcare, Erlangen, Germany) mid short axis cine SSFP BOLD sequence (as previously described $^{1}$ ) was performed at baseline and during graded ACh infusion in the LCX $(0.1 \mu \mathrm{g} / \mathrm{min}, 1.0 \mu \mathrm{g} /$ min and $10 \mu \mathrm{g} / \mathrm{min})$. Scan parameters were: field-ofview 228 x $280 \mathrm{~mm}$; matrix size 125 x 192; in-plane resolution $1.8 \times 1.6 \mathrm{~mm}$; slice thickness $5 \mathrm{~mm}$; TR/TE $5.8 \mathrm{~ms} / 2.9 \mathrm{~ms}$; flip angle $90^{\circ}$; readout bandwidth

${ }^{1}$ Stephenson CMR Centre / University of Calgary, Calgary, AB, Canada Full list of author information is available at the end of the article
$275 \mathrm{~Hz} / \mathrm{Px}$; signal averages 1; typical breath-hold 16 seconds. CMR imaging was repeated with $10 \mu \mathrm{g}$ ACh after pharmacological blockage of endothelial NOsynthetase by $\mathrm{N} \omega$-nitro-L-arginine methyl ester (L-NAME). Coronary flow, coronary sinus (CS) oxygen saturation (SvO2) and BOLD-CMR imaging were performed simultaneously. Images were analyzed using clinically validated software $\left(\mathrm{cmr}^{42}\right.$, Circle cardiovascular imaging, Calgary Canada).

\section{Results}

Pharmacological interventions and image acquisition was successful in all dogs. Compared to baseline there was a significant increase in LCX flow at each ACh infusion grade $(28 \%, 86 \%, 210 \%)$, which was accompanied by significant increases in CS SvO2 $(3.6 \%, 5.3 \%, 15.7 \%)$ and in BOLD-CMR SI (means and confidence intervals) (2.7\%, 0 to $5.8 \%, \mathrm{p}=0.05 ; 3.5 \%, 0.4$ to $7.0 \%, \mathrm{p}<0.05 ; 8.0 \%$, 4.2 to $11.3 \%, \mathrm{p}<0.01)$. Compared to baseline, after L-NAME administration, flow response to the highest level of ACh was blunted (20\%) and no significant increase of BOLD-CMR signal intensity was found (1.9\%). Figure 1.

\section{Conclusions}

BOLD-sensitive CMR allows for non-invasive imaging of changes in myocardial oxygenation induced by endothelium-dependent vasodilatation. Further studies should address the utility of BOLD-CMR in the clinical setting of endothelial function testing. 


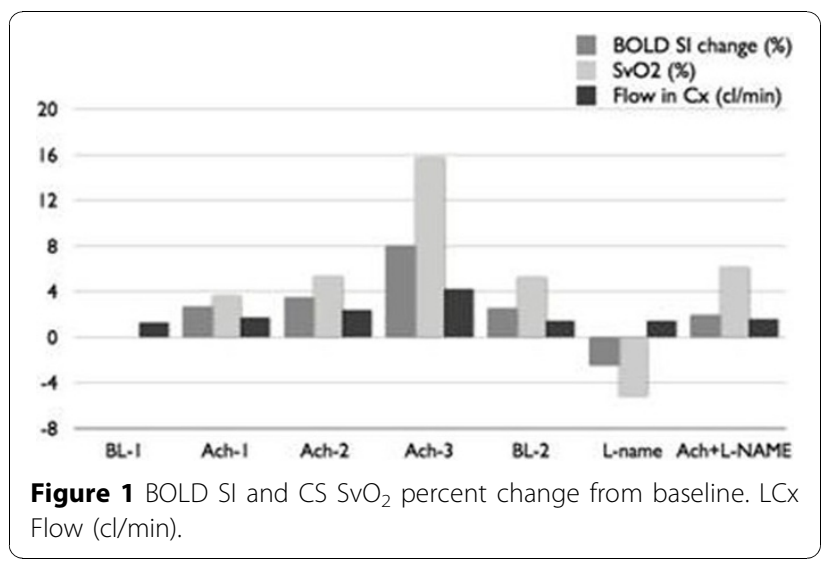

\section{Author details}

${ }^{1}$ Stephenson CMR Centre / University of Calgary, Calgary, AB, Canada.

${ }^{2}$ Robert-Bosch-Krankenhaus, Stuttgart, Germany. ${ }^{3}$ Siemens Healthcare, Calgary, AB, Canada. ${ }^{4}$ Libin Cardiovascular Institute of Alberta/University of Calgary, Calgary, AB, Canada.

Published: 2 February 2011

\section{Reference}

1. Dharmakumar R, Arumana JM, Larson AC, et al: Cardiac phase-resolved blood oxygen-sensitive steady-state free precession MRI for evaluating the functional significance of coronary artery stenosis. Invest Radiol 2007, 42:180-188.

doi:10.1186/1532-429X-13-S1-P53

Cite this article as: Jacqueline et al:: Assessment of coronary endothelial function using blood oxygenation level dependant cardiovascular magnetic resonance imaging (BOLD-CMR) in a canine model. Journal of Cardiovascular Magnetic Resonance 2011 13(Suppl 1):P53.

\section{Submit your next manuscript to BioMed Central} and take full advantage of:

- Convenient online submission

- Thorough peer review

- No space constraints or color figure charges

- Immediate publication on acceptance

- Inclusion in PubMed, CAS, Scopus and Google Scholar

- Research which is freely available for redistribution

Submit your manuscript at www.biomedcentral.com/submit 